\title{
FACTORS INFLUENCING THE CHOICE OF THE SOCIAL PROFESSION 'TEACHER'
}

\author{
Mariya Teneva ${ }^{1}$, Zlatka Zhelyazkova ${ }^{2}$
}

\begin{abstract}
This article is aimed at revealing the specifics of the professional choice made by students-future teachers. The increased interest in recent years of young people in studying pedagogical specialties provoked our research attention towards differentiating the factors influencing their professional choices. This article presents the results of a study conducted with students majoring in "Primary school pedagogy with a foreign language" who study at the Faculty of Education at Trakia University, Stara Zagora, Bulgaria. The results of the study indicate that in their professional choices, students are influenced by a wide range of social and personal factors. The most important social factors are: proximity of the university to the place where the student resides, the high social assessment of the quality of education at the university/faculty, and the prestige of the teaching profession in society. Among the personal factors for choosing the profession of pedagogue, students rank in leading positions their desire to work with children and their love for the teaching profession, formed under the influence of the high professionalism of their good teachers.
\end{abstract}

UDC Classification: 37, DOI: https://doi.org/10.12955/pss.v2.244

Keywords: education, teaching profession, factors for professional choice.

\section{Introduction}

In retrospect of time, the teaching profession is characterized by its long traditions. The name "teacher" comes from the ancient Greek word "didaskalos", whose meaning is associated with "educator"/'a person authorized to teach other people/'. The need for the accumulated labor and social experience to be passed on from the knowledgeable and the able, to the ignorant and incapable has existed for millennia. Although in elementary form, from the very beginning of rational human existence one can speak of the realization of training without it being based on professional grounds. In his scientific publications Iskrev points out that phylogenetically the profession came out as a result of the division of labor (Iskrev, 2000). As the volume and complexity of the acquired knowledge and experience increased, the need for division of labor arose. People started to specialize in certain areas. This can be seen as a prerequisite for the later emergence of the different professions. Ancient in its nature, over the centuries the teaching profession has evolved and improved so as to nowadays become necessary for the prosperity of modern society. Do young people make sense of these valuable characteristics that make the analyticity teaching profession attractive to them? Is their professional choice characterized by deep analyticity, or is it made under the influence of random factors? This article attempts to adequately answer these, important for the modern society, questions.

\section{Factors Influencing the Choice of the teaching profession}

\section{Literature Review}

In his conscious life, man is free to make a number of choices, some of which are so important that they can model their human existence and can be defined as fateful. Along with the choices of personal identity or the choice of a partner in life, a significant influence on the existence of the individual can be the choice of profession. Solovyov (2013) popularized his ideas for the free choice of profession. He presents in a schematic form a model for choosing a profession which is characterized by three key factors - abilities, interests and the labor market, between which there are several areas of intersection. The author emphasizes the importance of three key sections that influence the choice of profession, namely: the coincidence between the interests and the abilities of the individual, the synchronization between personal and public interests and the possibility of a free choice of profession (in unison with the abilities of the individual); based on the possibility for realization on the labor market. Solovyov (2013) does not try to present a "recipe" for a successful professional choice, but to defend the idea that the individual has the opportunity for professional choice and should take advantage of it (Solovyov, 2013). A similar idea in the Bulgarian scientific literature is presented by Vassilev and Merdjanova (2003). Both authors believe that the choice of profession should be made in accordance with the interests of the individual (determining their preferences and ambitions in the sector of what is desired); the abilities and qualities of the personality (defining their capacity as opportunities and limitations in

\footnotetext{
${ }^{1}$ Trakia University, Faculty of Education, Stara Zagora, Bulgaria, m.s.teneva@abv.bg

${ }^{2}$ Trakia University, Faculty of Education, Stara Zagora, Bulgaria, zlato6ki@abv.bg, ORCID: https://orcid.org/0000-0001-9982-0268
} 
the sector of what is available); the characteristics of the labor market and the profession - the objective context of the choice" (Vassilev \& Merdjanova, 2003, p. 20). Petkova (2012) points out that "the choice of profession is a deeply personal act, the implementation of which is connected with all mental aspects of the personality. On the one hand, it must be based on purely cognitive, conscious processes. On the other hand, the choice of profession is based on our desires, interests and preferences in one or other area, which is inherent in the emotional, affective side of the personality. Thirdly, the choice of profession is also a behavioral, conative act, which at a certain stage of its ontological development each person makes and activates through the exercising of a profession" (Petkova, 2012, p. 99). This opinion presents the idea of the mutual influence of different groups of factors in the choice of profession, in particular the teaching profession.

Brad Olson is another author who has popularized his model for choosing the teaching profession. He points out that entering and remaining in the teaching profession is influenced by the professional identity. According to him, views on teacher identity are the result of social psychology, philosophy and sociolinguistics. Based on a case study, the author differentiates between the factors which influence a teacher's professional identity (Olsen, 2008).

Milenkova outlines a psychological portrait of the teacher. She points out several factors that influence the professional choice. As such, the author points out: the essence of the profession itself and its social significance, the created idea of the inner life in the professional community, the possible professional belonging to the community. Among other factors influencing the choice of teaching profession, Milenkova also considers the possibility of the need of the young person to belong, i.e. be attracted to the relevant professional community. The author connects the affiliation to the professional-pedagogical community with the causal conditionality: "children, whose parents are teachers, easily and relatively quickly enter the "kitchen" of the teacher's life" (Milenova, 1979, p. 64). Positive attitudes and expectations towards the teaching profession and the inclusion of young people in the professional pedagogical community could be influenced in a positive way not only by parents but also by the good example of practicing teachers. As Shivacheva (2020) points out, "the modern educational paradigm brings out as a socially valuable idea that of humane and oriented towards the person attitude towards the child/student" (Shivacheva, 2020, p. 961). Through their humanism, high professionalism, personal involvement and dedication teachers can reveal the usefulness and the attractiveness of their profession before the students and awaken in them the desire for a conscious choice of the teaching profession.

The choice of the teaching profession can be influenced by the prestige of the profession in society. One of the factors that determines the prestige of the profession is the payment of the people who practice the profession that is relative to the level of their standard of living. The state of the labor market presupposes conditions for professional realization, career growth, gradual increase of income, realization of differentiated payment of teachers, which is clearly regulated by a large set of normative documents (Ordinance № 1 of 04.01.2010; Ordinance № 12 of September 1, 2016, the National Classification of Professions and Positions in the Republic of Bulgaria, 2010, the National Program "Differentiated Payment") - these are motivating factors that provoke the individual to choose purposefully and convincingly the teaching profession.

One of the factors that influences the professional choice of a teacher is the state of the labor market. The number of young people who, in a projective aspect, become aware of the opportunities for professional realization in their chosen profession is growing. The state's governing bodies are working purposefully to create a close connection between educational institutions and real business. There is a clearly declared state policy for announcing priority areas in higher education, for which increased subsidies are provided. These declared priority areas train staff that our national economy needs. Some of the priority directions are "Pedagogy" and "Pedagogy of teaching ...", in which the future pedagogues are trained (Decree № 162, 2001). The amendments and supplements to that decree (State Gazette, 2016) regulate an increase in the subsidy for training of students in pedagogical specialties from 2017 onwards. Consequently, the increase in the state subsidy leads to a higher quality of education which helps to increase the interest of young people in mastering the teaching profession.

A successful professional choice has a positive projection on the feeling of satisfaction from the work done and creates a feeling in the person of acceptance by the social environment and facilitates the process of self-acceptance. It provokes personal desires and aspirations to increase one's professional competence and generates a conscious desire for personal self-improvement. This imposes the need over 
the last decade to work purposefully in the direction of conducting the so-called "career education" (Merdjanova, 2012, p. 79).

Regarding the modern type of person and his or her professional realization, Andreev (2015) asks the following important questions: "What type of person does society need today? - whether we need a person for a superpersonal profession or rather a choice of profession for the person according to his or her unique individuality" (Andreev, 2015, p. 118). When the choice of profession by modern man is made as a result of meaningful, long-lasting and purposeful professional self-determination, in accordance with the uniqueness of the human personality, it would be characterized by sustainability. In this case, the person, instead of repeatedly focusing on different professional choices, would concentrate on sustainable career development in a one-time, confident and meaningfully chosen profession, which for some young people may be the teaching profession.

\section{Data and Methodology}

The article presents the results of an empirical study conducted with students majoring in Primary School Pedagogy with a Foreign Language (English), who study at the Faculty of Education at Trakia University, Stara Zagora, Bulgaria. The survey was conducted in October, 2020. The respondents were given the opportunity to fill out a test-questionnaire anonymously. They were required to indicate their gender and their chronological age in years. The survey covered 44 respondents. Of these, $7 \%$ were male and 93\% were female. The age of the respondents varied between 18 and 25 years old. The main share of $89 \%$ was occupied by the students, covered in the study, whose age is in the range between 18 and 20 years old. The share of eighteen-year-old students is $21 \%$, of nineteen-year-old students is $52 \%$ and of the twenty-year-old students is $16 \%$. The total share of respondents aged $21-25$ years old is $11 \%$. The students covered in the study were given the opportunity to fill out a test-questionnaire aimed at revealing the specifics of the factors contributing to their professional choice. One of the goals was to differentiate the leading factors in choosing a university in which young people continue their education. Another goal, which was realized through the research, was to reveal the factors contributing to the specific choice of a specialty related to the mastery of a future profession.

In order to achieve the set goals, the following research methods were employed: content analysis, test, percentile analysis and rank scaling.

\section{Results and Discussion}

As can be seen from the graph in Figure 1, more than half of the students (52\%) are 19 year-olds. Second position in terms of numbers, $21 \%$, are the respondents whose age is 18 . They are followed by students aged 20, who represent a share of $16 \%$. Together, these three sections represent $89 \%$ of all students covered in the study. These empirical data are an indication that the social profession of educator is attractive to high school graduates. Immediately after graduating from high school, many of them apply to university, choosing to master the teaching profession. The fact that young people want to be trained as teachers is a favorable precondition for the future of this profession. The Ministry of Education and Science in Bulgaria has announced alarming data on the aging of staff in the field of education. The results of the present study are an indication that this problem will be overcome in the foreseeable future. Another issue under discussion is the finding of prevailing feminization of the teaching profession in Bulgaria. A very small number of male students choose pedagogical specialties at the university. This is confirmed by the presented research data. Only $7 \%$ of the respondents are male. The remaining $93 \%$ are women. While at the beginning of the 20th century the teaching profession was practiced mainly by men, in the 21 st century being a teacher is a professional choice mainly made by women. Since teachers are perceived by students as authoritative individuals, it would be good for them to be able to interact with both female and male teachers in the learning process. At this stage, the pedagogical interaction is carried out mainly by female teachers.

One of the aims of the research is to establish what factors influenced the choice made by young people involved in higher education of the particular university in which to continue their education. In the first question of the test-questionnaire the respondents are required to rank from 1 to 6 in order of importance the factors, among the set provided to them, which have influenced their choice of university. They could select and rank from the following six options: "the university's high rating; the good reviews of other students studying at this university; this university is located in/near the settlement where I live; 
the amount of tuition fees; I applied to other universities, but I was not admitted there; I made a random choice of university".

The results of the research from the first question, which indicate the leading factors for choosing a university, are presented as follows:

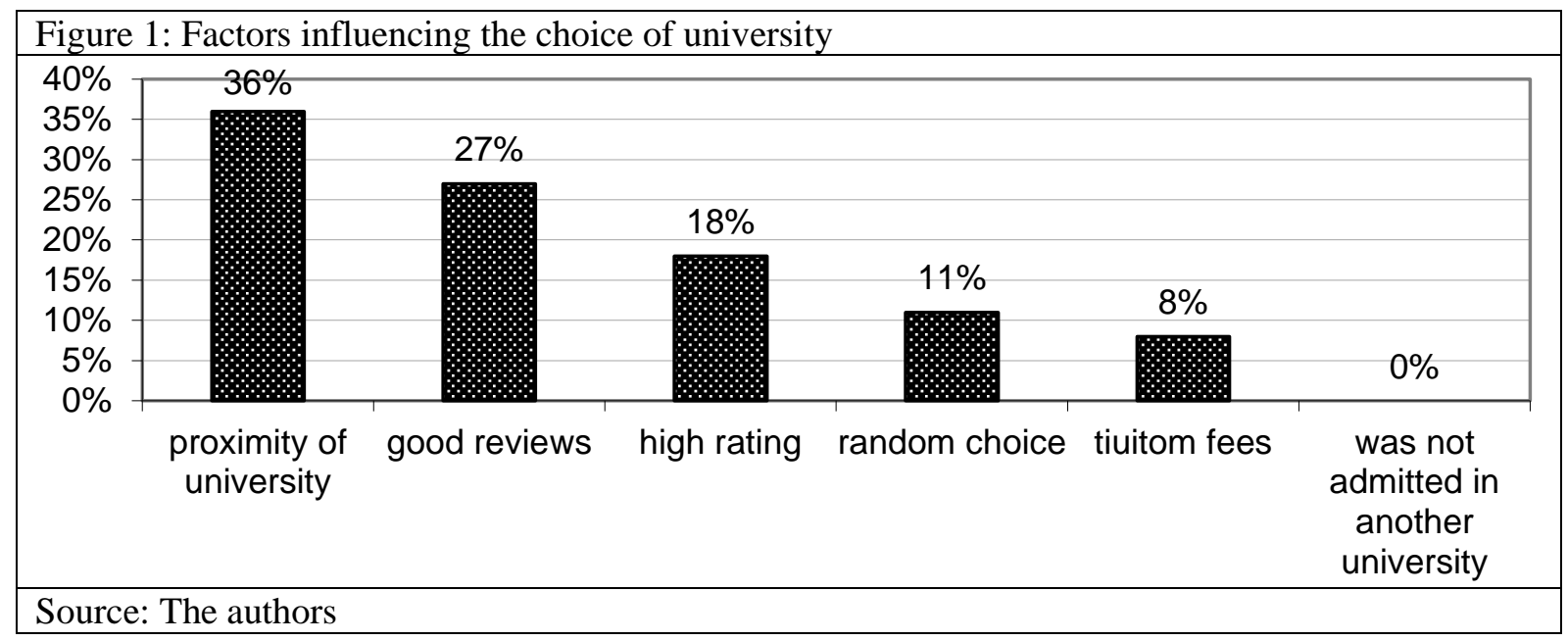

In Figure 1, the specifics of the ranking scale for the factors influencing the choice of a university in which young people continue their education can be traced.

In the first position in the ranking scale, the respondents put the proximity of the university to where they live. Such an answer is valid for $36 \%$ of the students covered in the study. The proximity of the university to the hometown is an important social factor that influences the choice of university by students. In the complex times we live, characterized by labor market insecurity and income dynamics, young people prefer to study in/near the place where their home and parents are. This circumstance guarantees the provision of housing for which the students will not pay additional funds, as well as daily financial and material support that they can receive from their parents. This circumstance reveals a great financial dependence of young people in Bulgaria on their parents.

The second place in the ranking scale is occupied by the good reviews of other students who are already studying at the university. This answer was chosen by $27 \%$ of the respondents. From the specifics of this factor, highlighted as important for the choice of university, it can be assumed that advertising based on "satisfied consumer of educational services" is extremely important. The public response to the quality of education at a university nuances the motivation for its choice by prospective students. In the age of rapid development of information technologies, digital media is gaining more and more popularity among people. Young people are looking for answers to questions that excite them by discussing them with their friends, especially on social networks. When, through conversations with friends or social media sharing, they find good feedback on the quality of education and career opportunities of other young people who are already studying at a particular university, they tend to trust them and choose to study in the same university.

In third place among the factors influencing the choice of university, the students have placed "the high rating of the university". This answer was given in third place by $18 \%$ of the respondents. Since 2010 , data from the ranking of Bulgarian universities (Rating system of the Universities in Bulgaria) are carried out in our country annually by the Open Society Institute and are promoted by the Ministry of Education and Science. Rankings are made between 52 higher schools. In 9 of them the professional field of Pedagogy is accredited. Although existing for only 10 years, the rating system of higher education institutions has gained wide popularity in our society. Research data indicate that prospective students are influenced in their choice of university by these rankings. For the period for which a database is bring maintained (2012-2020), the Faculty of Education at Trakia University sustainably occupies the prestigious 2nd place (in 2012, 2014, 2016, 2018, 2019) and 3rd place (in 2013, 2015, 2017, 2020). Candidate students follow this positive trend of high prestige in the professional field of Pedagogy at Trakia University and confidently choose to continue their studies there.

The fourth position in the ranking scale for the factors influencing the choice of higher education is occupied by the answer "I made a random choice". This is valid for $11 \%$ of the students covered in the 
study. Despite the opportunity to choose from 52 universities in Bulgaria and a huge number of universities abroad and the easy access to information about universities on the Internet, $11 \%$ of young people randomly choose a university where they continue their education. In order to keep this group of students in higher education, their involvement in the academic community, the discovery of the attractiveness of the profession they have chosen to learn and their motivation for effective learning, which are carried out as a result of interaction with university professors, are crucial.

The fifth position in the ranking scale is occupied by the "amount of tuition fees" answer. This answer was given by $8 \%$ of the respondents. This is another important social factor that influences the choice of higher education by young people. Although their percentage is not high, some students, when choosing a university, take into account the financial amount of the semester tuition fees at the university. The age distribution of the respondents shows a tendency that the majority of students (89\%) are very young, aged 18-20. These are young people who in the respective year graduate from high school and immediately after that start their studies at the university. They do not work, so have no income on their own and rely on the help of their parents for their financial support. It is important for them whether the costs of tuition fees, as well as other expenses for their maintenance, will be able to be included in the general family budget.

The answer in the last sixth position is "I applied to another university, but I was not admitted". This answer was not chosen by any of the respondents. Despite the fact that $11 \%$ of the surveyed students indicated that they had made a random choice of university, this was their only choice. Years ago, young people in Bulgaria preferred to apply to several universities simultaneously and expect their best ranking in their desired professional field and specialty. The results of the research indicate that this trend is no longer valid. Respondents indicated that their choice of university, although not preceded by professional orientation and professional self-determination, was the only one. After revealing the specifics of the factors that influence the choice of university for young people, our research attention was focused on differentiating the factors of their professional choice. Respondents were asked to answer the question "What motivated you to choose to master the teaching profession?" The students had the opportunity to choose between the following eight options: a) the payment for teaching; $b$ ) there are other teachers in my family; c) the good example of my teachers; d) the vocational guidance they did with us in high school, e) my desire to work with children; f) at the insistence of my parents; g) I applied for other specialties but was not admitted in them; h) I made a random professional choice. The results are presented as follows:

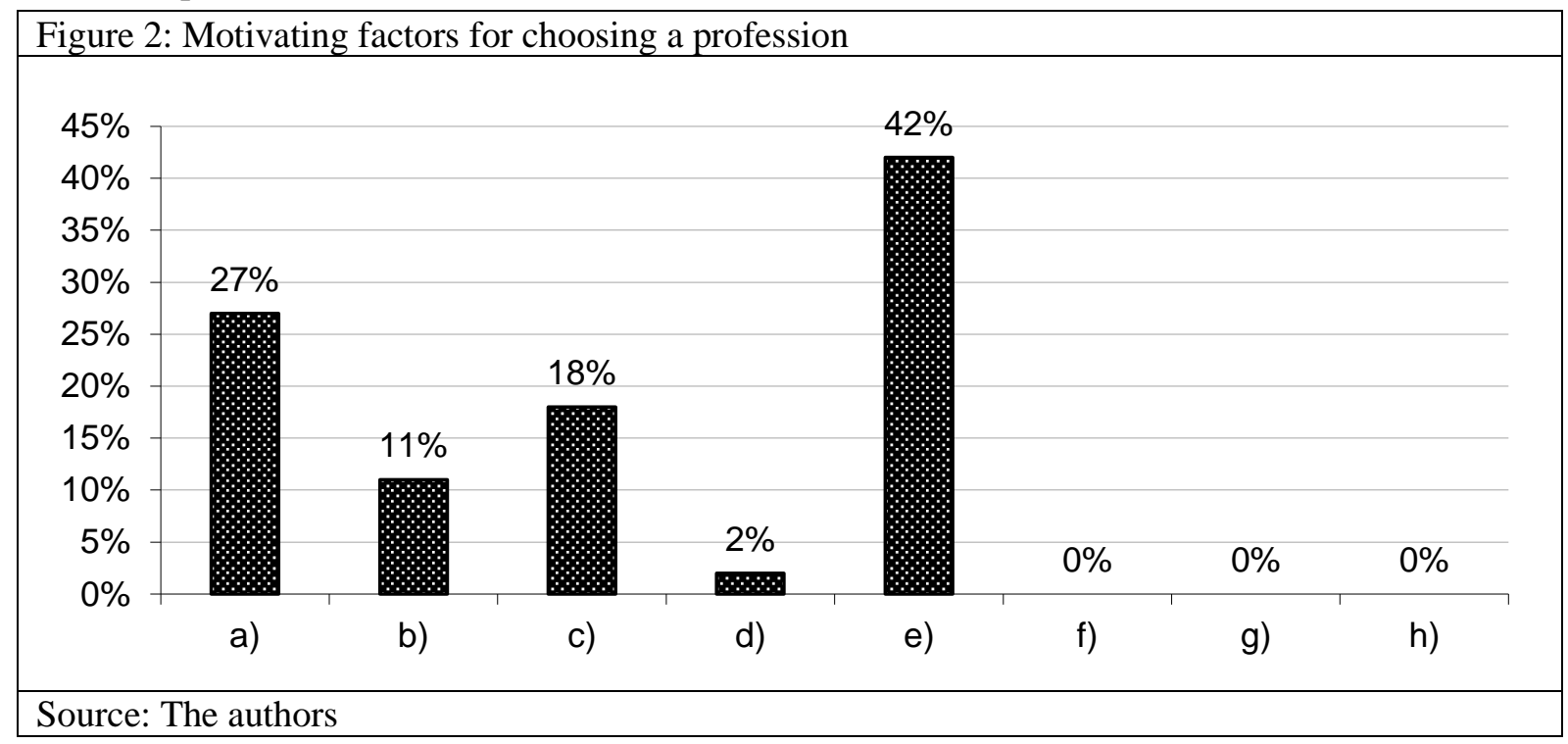

From Chart 2 it can be established that the respondents have preferred 5 of the 8 answer options offered to them. The largest share is occupied by students majoring in "Primary School Pedagogy with a Foreign Language" for whom a motivating factor in the professional choice is their desire to work with children. This answer is provided by $42 \%$ of the respondents. The profession of primary school teacher requires daily interaction with children. In this aspect, the love for children and the desire of the students to work with children can be considered favorable prerequisites for purposeful and successful professional 
choice. This motivating factor corresponds with the highest degree to social nature of the teaching profession.

The next largest share is presented by students who have chosen to study in a pedagogical specialty due to the high pay of teachers. This answer is preferred by $27 \%$ of respondents. In order to increase the prestige and attractiveness of the teaching profession, the state policy in our country is aimed at gradually increasing the salary of teachers. When the professional efforts of those working in the field of education are rewarded with dignity, this has a positive effect on the prestige of the profession in society and motivates young people to choose to become teachers. High salaries guarantee a good standard of living to which those who choose the teaching profession aspire.

In $18 \%$ of the cases, the respondents are motivated to choose the teaching profession influenced by the good example of their teachers. This is a certificate for the high professionalism of the teachers working in Bulgarian schools. Through their effective interaction with students, they manage to highlight the best aspects of the teaching profession. They turn students into their supporters, provoke their desire to choose as their future realization the humane profession of a teacher.

For $11 \%$ of the respondents, the choice of the teaching profession is a continuation of a family tradition. This group of students indicates that there are other teachers in their family. In their professional choice, they are influenced by the positive aspects of the profession, which is practiced by the people closest to them - parents, brothers, sisters. The family is an important educational factor that influences the professional choice of children. In families where children choose to dedicate themselves to their parents' profession, parent-child interaction is based on mutual understanding, dedication, sharing high professional success, and parental satisfaction with practicing their profession. This makes children want to be like their parents, to continue their career and to practice their professions.

One of the functions of pedagogical advisors in schools is to assist in the professional and vocational orientation of students. This function is extremely important in the high school stage of education, when high school students are directed to choose specialties in higher education. Only $2 \%$ of the respondents indicate that in choosing a future profession they are influenced by the professional orientation they have had in high school. This fact is indicative of the ineffective activity in this direction of the pedagogical advisers in the high school stage of education.

The answers "f) at the insistence of my parents; g) I applied for other specialties, but I was not admitted in them; h) I made a random professional choice" have not been indicated by the respondents. These three factors are not highlighted by students as important for their choice in pursuing the teaching profession.

The results of the research indicate that students choose a university for their studies under the influence of various factors. A large set of motivating factors provokes them in choosing the teaching profession. Professional choice is the final stage of the process of professional self-determination of the individual. In this aspect, our research interest was attracted in establishing the sustainability of the respondents' professional choice. They were given the opportunity to answer the question "Has your attitude towards the teaching profession changed since you started your studies at the university?". The possible answers are presented on a five-point scale: a) yes (in a positive aspect); b) yes (in a negative aspect); c) rather yes; d) rather not; e) no. The largest share of students (57\%) have changed in a positive way their attitude towards the teaching profession after entering the university. The specialized academic disciplines which reveal in detail the specifics of the teaching profession and the effective interaction between students and university professors, contribute to the inclusion of the students in their future profession. They reveal the importance of the primary teacher's profession for the education, socialization and personal development of the young student. The results do not indicate the presence of students who, after starting their studies at the university, are disappointed with their professional choice and have negatively changed their attitude towards the teaching profession. The answer "rather yes" is valid for $20 \%$ of the respondents. $7 \%$ of the students who choose the answer "d) rather no" and $16 \%$ are those who choose the answer "e) no" which explains that they had a positive attitude towards it when choosing the teaching profession and as a result of their university education it remains positive. As the results indicate that $100 \%$ of the respondents have a positive attitude towards the profession, the next question is aimed at verifying the validity of this answer. Students are asked to answer the question, "Do you think you have made a good professional choice for your life?" They are given the opportunity to choose 
an answer on a five-point scale: a) yes; b) rather yes; c) rather not; d) no; e) I can't say. The specifics of the answers to this question reveal the presence or absence of a correlation between the respondents' attitude towards the profession and the belief in the expediency of their professional choice.

The distribution of data in the five sectors of the scale is disproportionate. All answers are concentrated at the beginning of the scale, in the first two sectors. The largest share is occupied by the respondents who confidently believe that they have made a good professional choice for their life. This answer is valid for $75 \%$ of the students covered in the study. The second position is occupied by students who experience some hesitation but are more confident that their professional choice is good. There are no registered answers from students who are hesitant about the appropriateness of their professional choice or think it is not good. The presence of respondents who find it difficult to assess the appropriateness of their professional choice has not been established. A correlation between the answers to the last two questions is revealed. It is established that all surveyed students majoring in "Primary School Pedagogy with a Foreign Language" have a positive attitude towards the teaching profession and they all express their conviction in the appropriateness of their professional choice. This is an indicator of the reliability of the answers given by the respondents, as they are interrelated. When students have a positive attitude towards the profession and believe that the professional choice they have made is the best for their lives, it contributes to their high level of motivation in acquiring professional-theoretical and practical competence in their academic training at university

\section{Conclusion}

The results of the research give grounds to make the following theoretical summaries.

When choosing a higher education institution in which they continue their education, young people are guided to the highest degree by the proximity of the university to the settlement in which their permanent residence is located. This choice is dictated by social and financial reasons. It was clearly established that the factors for the quality of education in the respective higher education institute, as well as the position of the university, can also be considered as factors of high importance for choosing a university. The choice of the socially valuable social profession of the pedagogue is influenced by a large complex of personal and social factors. Of great importance are the desire of future teachers to work with children, as well as the prestige of the teaching profession, based on the decent salary of teaching.

Young people have a positive attitude towards the teaching profession. The positive attitude towards the profession stated by them is in correlation with the expressed conviction in the expediency of their professional choice.

The added value of the present study lies in the creation of a new vision for the teaching profession. The traditional notion that this is an outdated, boring and unattractive profession has been replaced by the opinion expressed by the students in the study about the attractiveness, humanity and the appeal of the teaching profession. Based on the construction and testing of the author's tools, two significant ranking scales have been derived. The ranking scale for the factors influencing the choice of higher education is valuable for university professors. It sets strategic goals for the development of higher education institutions in order to meet the needs of society and to attract future students with the high quality of education that they can provide. The ranking scale for the factors of professional choice creates a clear vision of the motives of young people in choosing the profession of the teacher. This scale is important for the governing bodies in the education system. It helps to create credible national strategies for attracting and retaining young people in the field of education.

\section{References}

Andreev, M. (2015). Razmisli za obrazovanieto |Thoughts on Education]. Sofia: published by "East-West".

Decree № 162 of 20.06.2001 of the Council of Ministers

Iskrev, D. (2000). Osnovi na profesionalnoto orientirane [Basics of Vocational Guidance]. Blagoevgrad, pp. 35

Merdjanova, Y. (2012). Evropeřskoto karierno obrazovanie v bŭlgarski usloviya [European career education in Bulgarian conditions]. Pedagogy, 1. Sofia.

Milenkova, V. (1997). Uchitelyat - sotsiologicheski portret [The Teacher - a Sociological Portrait]. Sofia

Naredba № 1 ot 04.01 .2010 g. za rabotnite zaplati na personala $v$ zvenata ot sistemata na narodnata prosveta (obn. DV, br. 4 ot 15.01.2010 g. i posl. izm. i dop.) [Ordinance № 1 of 04.01 .2010 on the salaries of the staff in the units of the system of public education (promulgated in the State Gazette, issue 4 of 15.01.2010 and later amended and supplemented)] 
Naredba № 12 ot 01.09.2016 g. za statuta i profesionalnoto razvitie na uchitelite, direktorite i drugite pedagogicheski spetsialisti (obn. DV, br. 75 ot 27.09.2016 g., v sila ot 27.09.2016 g.) [Ordinance № 12 of 01.09 .2016 on the status and professional development of teachers, principals and other pedagogical specialists (promulgated in the State Gazette, issue 75 of 27.09.2016, in force since 27.09.2016)

Natsionalna klasifikatsiya na profesiite i dlŭzhnostite [National Classification of Occupations and Positions], 2011 (in force since 1 January 2011). Sofiya: Publishing House "Trud i pravo"

Natsionalna programa „Diferentsirano zaplashtane” [National program "Differentiated payment"], [retrieved from http://www.mon.bg on 09.03.2021

Olsen, B. (2008). How reasons for entry into the profession illuminate teacher identity development. Teacher Education Quarterly, Summer, 2008, retrieved from http://eric.ed.gov/PDFS/EJ831706.pdf

Petkova, I. (2012). Podgotovka i kvalifikatsiya na bŭlgarskiya uchitel [Training and qualification of the Bulgarian teacher]. Sofia: "St. Kliment Ohridski" University Publishing House

Postanovlenie № 162 na MS of 20.06.2001 za opredelyane na diferentsirani normativi za izdrŭzhka na obuchenieto na edin student po profesionalni napravleniya [Decree № 162 of the Council of Ministers of 20.06.2001 for determining of differentiated norms for maintenance of the education of one student in the professional fields] (promulgated State Gazette, issue 59 of 03.07.2001, in force from 01.01.2002) and later amended and supplemented)

Rer̆tingova sistema na visshite uchilishta v Bŭlgariya [Rating system of the higher schools in Bulgaria], /rsvu4/\#/, retrieved from https://rsvu.mon.b on 09.03.2021]

Soloviev, AP (2013). Vybor professii [Choice of Profession]. Moscow: Publisher "Exmo".

Shivacheva-Pineda, I. 2020. Balans v pedagogicheskite vzaimootnosheniya [Balance in the Pedagogical Relations], Pedagogy, volume 92, (7)

State Gazette, issue 69 of 02.09.2016

Vasilev, D., Merdjanova, Y. (2003). Teoriya i metodika na profesionalnoto orientirane [Theory and Methodology of Vocational Guidance]. Sofia: "St. Kliment Ohridski" University Publishing House. 